International Research Journal of Management, IT \& Social Sciences
Available online at https://sloap.org/journals/index.php/irjmis/
Vol. 8 No. 3, May 2021, pages: 204-218
ISSN: 2395-7492
https://doi.org/10.21744/irjmis.v8n3.1468

\title{
Application of Ethical Leadership and Workers' Performance: A Perspectives from Public and Private Owned Enterprises
}

Anthonia Awele OLANNYE ${ }^{\text {a }}$

Article history:

Submitted: 9 January 2021

Revised: 18 February 2021

Accepted: 27 March 2021

Keywords:

enterprises;

ethical;

leadership;

worker performance;

\begin{abstract}
The main objective of the study was to determine the rationale of ethical leadership in public and privately-owned enterprises. It involved two public sectors and two private sector enterprises, which comprised 221 respondents from the staff and management of the enterprises as the sample size for the study. The survey research method was used in gathering information from respondents. A stratified sampling technique was adopted for the study. A validated structured questionnaire was used for data collection. The statistical techniques adopted for processing the data and testing the hypotheses for this study compared mean using independent t-test via the use of statistical package for social science (SPSS) software version 21 . Descriptive statistics and frequency analysis were used. The mean response was tested using a t-test. The findings of the study revealed that there is no significant difference in ethical leadership between the public and private enterprises given that the variables revealed thus $(\mathrm{Sig} .=.728, \mathrm{P}>0.05)$ and $(\mathrm{Sig} .238, \mathrm{P}>0.05)$. The study concluded that the leadership of the public and private enterprise should have the ethical values, interpersonal qualities and capabilities to carry out the different tasks as needed by the organizations.
\end{abstract}

International research journal of management, IT and social sciences (C) 2021. This is an open access article under the CC BY-NC-ND license (https://creativecommons.org/licenses/by-nc-nd/4.0/).

\section{Corresponding author:}

OLANNYE, A. A.

Faculty of Management Sciences, Department of Business Administration and Marketing, Delta State University, Asaba Campus, Nigeria

Email address: awaele.olannye@gmail.com
${ }^{a}$ Faculty of Management Sciences, Department of Business Administration and Marketing, Delta State University, Asaba Campus, Nigeria 


\section{Introduction}

When the staff of a public or private enterprise is asked to choose a leader, most people may go for the same person. Taking a look at the overwhelming choice closely, you will discover that he is not just popular in the artificial view, but one will discover that he gives out selfless service especially to the actualization of the desires of the working populace. Such individuals are often those that see beyond the now of their own direct needs but that of others in the establishment. However, events may occur which may change the status of the particular individual. The organization of the group may also differ based on the job which challenges it. This proposes that leadership is dynamic and situational. Ethical leadership is a concept that appears to be uncertain and includes various components. Instead of perceiving ethical leadership as preventing people from carrying out inappropriate acts, authors suggest that one should view it as enabling people to do the right thing. Wayne (2009) argued that we must treat others with respect. To do so means always to treat others as ends in themselves and never as means to ends. "Persons must be treated as having their own autonomously established goals and must never be treated purely as the means to another's personal goals." These writers then suggested that treating others as ends rather than as means requires that we treat other people's decisions and values with respect: failing to do so would signify that we were treating.

Ethical leaders always set their eyes on the long-run consequences, shortcomings and profits of the decisions they make in the organization (Freeman et al., 2006). They exhibit humility, concerned for the benefit of all, strive for equality, shoulder responsibility and display respect for each individual. Ethical leaders set tall ethical standards and act likewise with them. They impact ethical norms through their behaviour. Leaders are seen as role models to their followers and exhibit the behavioural limits set by the business. Hence, the leader "walks the talk", the more the level of trust and respect he garners from followers (Freeman et al., 2006; Brown et al., 2005).

Obadan (2000) many reasons for the formation of public enterprises and that is economic growth, also in many developing countries, the means accessible to the private sector are not adequate for certain goods and services, nations such as United Kingdom, France, Canada, Turkey and Nigeria, which implemented mixed economy, the government have now accepted the apparent truth that if most enterprises were turned over to the private sector they would be better managed and their economy would fare better. In Africa, the poor show of Public Enterprises attracted a lot of condemnation, mainly in the 1980s as the macroeconomic policy environment arising from the impacts of the crisis became less accommodating to the resulting inefficiency in resources allocation. This research tends to compare ethical leadership in private and public enterprises.

Businesses today experience a rapid communication system, managers of a firm cannot afford to engage in unethical practices because of the damaging effect but also the harmful publicity that it will create and the consequent impact on the value. The deficiency of ethical leadership in Nigeria has badly affected stakeholders and caused many to lose interest in the system. The existence and constancy of any enterprise be it public or private is dependent on the quality of its ethical leadership. Despite numerous reforms introduced by the government to strengthen public and private enterprises, an unethical attitude abounds. The unethical practice seems to have intensified over time in past decades which have accounted for various unruly behaviour. Public and private enterprises will be heading towards shutting down and eventual collapse should unethical practices continue. The annoyance of the Nigerian Public enterprises has been that of emphasized roles, it is puzzling to play a welfare role and run a profitable venture. The image is so depraved that it has come to denote inefficiency, red-tapism, lack of initiative and corruption, this may not be justified but it reflects apparent dissatisfaction with public establishments.

This has led to the fact that public and private enterprise respectively has failed to live up to potentials through declining personal values, social values, moral values and value of competition. The difficulties of both public and private enterprises are multifaceted such as operational inefficiency, poor employee's relation, overstaffing, lack of coordination at the staff level, poor motivation, conflicting objective and functional connection disorder that is, underutilization of staff. Hence, this study tends to investigate the comparative analysis of ethical leadership in public and private enterprise. Objectively, the study is to examine whether personal values affect ethical leadership in public and private enterprises and determine whether social values affect ethical leadership in public and private enterprises.

\section{Research Hypotheses}

1) $\mathrm{Ho}_{1}$ : There is no significant difference between personal values and ethical leadership in public and private enterprises.

2) $\mathrm{Ho}_{2}$ : There is no significant difference between social values and ethical leadership in public and private enterprises.

OLANNYE, A. A. (2021). Application of ethical leadership and workers' performance: A perspectives from public and private owned enterprises. International Research Journal of Management, IT and Social Sciences, 
Review of Related Literature

Conceptual Framework

Concept of Ethics

Ethics originated from the Greek word "ethos" meaning custom or character. It is apprehensive with describing moral requirements and behaviours, which suggests that there are acceptable and unacceptable ways of behaving that serve as a function of philosophical principles. It is a continuous discovery and reaffirmation and evaluation of own values and principles (Freeman \& Stewart, 2006). Ethical leadership is a construct that appears to be ambiguous and includes various diverse elements (Yukl, 2006). Similarly, Brown defined the concept as "the demonstration of normatively appropriate conduct through personal actions and interpersonal relationships, and the promotion of such conduct to followers through two-way communication, reinforcement and decision- making" (Brown et al., 2005).

There is also the problem of criterion of good leadership as such; sometimes being ethical seems reasonable and appropriate in the short run and it is not right in the long run. A particular behaviour might be correct from the intraorganizational perspective but is incorrect in society. Sometimes, leaders have moral intentions, but their incompetence creates unethical outcomes (Ciulla, 2005; Brown \& Treviño, 2006).

\section{Concept of Ethical Leadership}

Ethical leadership is seen as "the demonstration of normatively appropriate conduct through personal actions and interpersonal relationships, and the promotion of such conduct to followers through two-way communication, reinforcement and, decision-making". Leadership is seen as a procedure whereby individual influences a group of individuals to achieve a common aim (Northouse, 2007; Dewi \& Dewi, 2018). Basic ways of becoming a leader are the trait leadership theory, observed as to where some personality traits may lead people naturally into leadership roles. A crisis or important event may cause a person to rise to the occasion, which brings out extraordinary leadership qualities in an ordinary person; this is the Great Events Theory addressing personality and characteristics in morality.

With the importance of good character and the right values, the reality of ethical leadership is far more complex and the stakes are much higher. In a similar vein, Freeman \& Stewart (2006) describe an ethical leader as a person with "right values" and "strong character" that set examples for others and withstand temptations. Ethical leaders are stakeholders in organisations, striving to achieve the purpose, vision and value of their realm without compromising self-interest. A leader should know that by living in harmony with these basic principles, the human enterprise can flourish and be sustained (Berghofer \& Schwartz, 2011). Ethical leaders should focus on moral values and fairness in decision making, consider the impact of organizational decisions on the outside world, and communicate to employees how their actions at work contribute to the overall goals of the organization.

Ethical leaders help give meaning to their employees' work and ensure that organizational decisions are based on sound moral values (Piccolo et al., 2010; Gallagher \& Tschudin, 2010). Ethical leaders make efforts to incorporate moral principles in their beliefs, values and behaviour; they are committed to a higher purpose, prudence, pride, patience, and persistence (Khuntia \& Suar, 2004). Also, a "moral person" is related to good character; the leader is honest and trustworthy, show concern for employee welfare and is seen as approachable. Whereas, a "moral manager," leads others on the ethical aspect, allow the employee to know what is expected, and holds them accountable.

Moral managers set ethical standards, communicate ethics messages, use the position of leadership to promote ethical conduct at work and use rewards and punishments to guide ethical behaviour in the organization. Trevino \& Brown (2004) expand the Executive Ethical Leadership Reputation by citing examples of leaders in each of the reputation matrix. Combining the "moral person" and "moral manager" dimensions creates a two-by-two matrix. A leader who is strong in both dimensions is perceived to be an ethical leader.

\section{Ethical Leadership and Employee Job Performance}

Toor \& Ofori (2009) revealed that ethical leadership may play a mediating role in the relationship between organizational culture and employee outcomes. The study shows that ethical leadership is more likely to bring about a leader's effectiveness, the willingness of employees to put in extra efforts, employees' job satisfaction, and an atmosphere for ethical leadership to flourish; which will ultimately lead to increased employees' job performance. Ethical leadership is associated with a positive influence on employee performance (Resick et al., 2011), intrinsic motivation (Piccolo et al., 2010), job responses (Ruiz et al., 2011; Aksiana \& Sujana, 2019) and willingness of an 
employee to report problems (Brown et al., 2005). Piccolo et al. (2010) suggest that leaders with strong ethical commitments can have an impact on "task significance" and "autonomy" of the Job Characteristic model; and the willingness of an employee to put extra effort into task performance. Two important variables are crucial to the issue of ethical leadership in improving employee job performance; trust and employee commitment. Berrone et al. (2007) opined that good ethics is good for business because it generates positive externalities like trust and commitment to all stakeholders, which in turn assures the long-term performance of firms.

\section{The leader's role in fostering ethical behaviour in organizations}

Leaders are the primary influence on ethical conduct in an organization and are responsible for the norms and codes of conduct that guide employees' behaviour (Bennis \& Nanus, 2005). Thomas believes that the motivation to be ethical comes from one's decision to live life in a certain way. If people opt to follow your leadership, they tend to follow that same conduct that you exhibit (Thomas, 2001; Walumbwa et al., 2011). The people namely watch the walk, they usually do not listen to the talk. In real life, one's behaviour depends both on the situation one finds himself in, as well as on standards of behaviour. It is relatively easy to wander off the correct path, as professional standards are more a vocational option than part of the territory (Kannair, 2007). 1n business world, an organization can voluntarily take on corporate social responsibility. However, there are no penalties if it chooses not to. In the table below, the criteria for the evaluation of ethical and unethical leadership are presented.

In their essay, Kouzes and Posner offer practical suggestions for being an ethical leader, explaining that this emanates not so much from the head as it does from the heart. Based on numerous interviews they conclude that love constitutes the soul of ethical leadership. They also observe that when working at their personal best - that means leading with love, with a feeling of warm personal attachment - leaders are transforming their followers into leaders. Love in an organizational sense creates the desire to see others grow and become better (Kouzes \& Posner, 1992).

\section{Public and Private Sector Management}

Public sector management, therefore, is a gracious merger of private-sector practices and the traditional aspects of public administration, giving public administration a sharper cutting edge in terms of risk-taking, flexibility, performance measurement, and goal achievement. Put simply, public sector management is the result of the integration of the best practices, processes and developments in the management of private sector organizations and public administration. This gives rise to a new way of conducting the business of the state (Pollitt \& Bouckaert, 2004). The combination of these three elements makes up the behaviours of a manager, with the argument that there isn't much difference between a manager in the public sector and the private sector. Besides the fundamental elements that make a manager in either the public or private sector, the public manager has a political role. The public sector manager "represents the whole society, to whom the public services are provided. The public managers are mostly political figures, elected or appointed for a determined period. This is the leadership definition for the public managers" (Demeter \& Tapardel, 2013; Kim \& Brymer, 2011), while the private managers are responsible to the board of directors and owners/shareholders. Nigeria is the most populous country in Africa and the largest concentration of black people in the world. She is one of the richest and most powerful nations in Africa, and she is currently the largest economy in Africa and among the first ten fastest-growing economies in the world. Unfortunately, she is among the most corrupt nations in the world with ineffective public sector performance (Mathews, 2002; Akintola \& Akintola, 2015).

\section{Public and Private Enterprises: A Comparison}

An enterprise can be defined as "a consciously coordinated social unit, composed of two or more people that functions on a relatively continuous basis to achieve a. common goal or set of goals" (Robbins \& Judge, 2013). Ogundele (2012) posit that an enterprise has a relatively identifiable boundary, which helps distinguish members from non-members. The boundary which can change with time may not be clear. Enterprises also have some continuing bonds which may not mean life-long membership, since enterprises face constant change in their membership. Enterprises can be differentiated into two generic groups: private enterprise and public sector enterprises. Private enterprise is owned and financed by individuals who are partners and/or shareholders in the company and are accountable to their owners or members. They vary widely in nature and size and the type of goods and services they provide.

Public sector enterprises are usually owned and controlled by the federal or state governments, headed by ministers appointed by the government. The appointment of the ministers is usually political and most of the ministers are posted

OLANNYE, A. A. (2021). Application of ethical leadership and workers' performance: A perspectives from public and private owned enterprises. International Research Journal of Management, IT and Social Sciences, 
to enterprises where they know little or nothing about (Ogundele, 2012). Public and private enterprises both have similarities and differences in the tasks, activities, contexts, personal demands and rewards of public and private executives? Jobs. Individuals are likely to weigh the relative importance. The similarities and differences are in sharply different ways depending on their personalities, values, cognitive styles and expectations. Thus, comparisons between government and business almost invariably contain significant elements of subjectivity and for this reason are difficult to interpret (Uche, 2012).

\section{Private Sector Organizations Performance in Nigeria}

The private sector in Nigeria has been dogged by weaknesses inherent in its skewed structure, indicated by a few multinational companies that are heavily imported- dependent. They mostly operate as enclaves and a large segment of essentially, informal sector, small and medium scale enterprises (SMEs) with very little, if any linkage to the huge multinationals and a rent-seeking and unproductive culture of over-dependence on government patronage and contracts. Nigeria, though embarked on a periodic development planning exercise as early as the 1960s, failed to realize the importance of the private sector and market-oriented policy in the process of overall development of the nation till the late 1980s and this resulted in several economic distortions.

However, a distinct departure took place in the overall development policy and strategies in the country, particularly after the adoption of the Structural Adjustment Program (SAP) in the mid-80s and the subsequent deregulation and liberalization of the economy. Consequently, under the new policy paradigm, a liberal policy anticipating the greater role of private initiatives in the economy has been in a place replacing the controlled economic policies practised under the Mixed Economic Approach (MEA). The private sector did not live up to expectations, despite the then favourable environment. The share of manufacturing industries in Gross Domestic Product (GDP) was still low, while capacity utilization was a little above 30 per cent (Iwara, 2007). Essentially, the performance of the Nigerian private sector vitiated the major assumption that underlines an International Monetary Fund (IMF) adjustment program the effect that the private sector can respond to supply-side incentives (Ekpo et al., 2008)

\section{Overview of Government's Effort to Promote Private Sector Development in Nigeria}

The rapid growth of a resilient and competitive private sector is a key component of a sustainable economic reform program. The present democratically elected government in Nigeria has put in a lot of efforts to diversify the nation's economic base, reduce the relative dominance of the oil sector and strengthen the linkages between the formal and informal sectors. Furthermore, this present administration has indicated its desire to increase the share of manufactured goods in total exports and generally create a vibrant private sector that can respond to the rigours of market forces, as its engine of growth (Lawanson, 2002).

The government has taken several steps towards realizing these objectives. Amongst such steps are: The establishment of the Nigerian Investment Promotion Commission. The establishment of Technology Business Incubation Centers designed to provide a conducive environment for nurturing the start-up and growth of new SMEs that would be engaged in value-added and technology-related manufacturing etc. Recently, to give the development of the private sector a boost, the government through the newly launched National Economic Empowerment and Development Strategy. (NEEDS) aims to: (a) Nurture science and technology-based SMEs in Science and Technology Parks (STPs) (b) Promulgate a law to give effect to the country's Competition Policy, a key component of the private sector growth strategy. Here, the major aspiration is to grow a private sector that can utilize the opportunities that abound in the domestic, regional and global markets. In addition to the foregoing measures, the government is committed to systematically work towards the mobilization of resources to facilitate the development of strategic economic infrastructure capable of improving the general attractiveness of Nigeria as a preferred investment destination.

Table 1

Comparison of Private and Public sector in Nigeria

\begin{tabular}{|c|c|c|c|}
\hline Management practice & Public sector (nigeria) & & Private sector (nigeria) \\
\hline Operations Management & Unclear & & Clear \\
\hline Human Resource Management & $\begin{array}{l}\text { Bureaucratic, } \\
\text { Influenced, }\end{array}$ & Politically & $\begin{array}{l}\text { Based on Merit, Motivated by } \\
\text { Efficiency. }\end{array}$ \\
\hline
\end{tabular}




\begin{tabular}{|c|c|c|}
\hline Performance Monitoring & " Limited, Less Frequent. & High, More Frequent. \\
\hline Incentive/People Management & $\begin{array}{l}\text { Poor, Fixed, Motivated by } \\
\text { Legislation. }\end{array}$ & $\begin{array}{l}\text { Motivated by } \\
\text { Performance. }\end{array}$ \\
\hline Decision Making & $\begin{array}{l}\text { Politically Motivated, Legislative } \\
\text { Approval, }\end{array}$ & Motivated by \\
\hline Financial Control & Merged with Administration. & Separated from Administration. \\
\hline
\end{tabular}

\section{Problems and Challenges of Private Sector Organizations in Nigeria}

Having briefly appraised the performances of the private sector as well as government policies (past and present) to promote the growth of the sector, this study wishes to share thought on the challenges facing the promotion of private sector-led growth in our efforts to achieve self-reliance. There are many challenges to be addressed to make the private sector vibrant and conducive for propelling economic growth. By and large, ensuring an investment-friendly environment and implementing adequate compensation policies for its employees is the key challenge before the nation. Private sector organizations, over the years, have been adversely affected: Limited access to funds in money and capital markets, Unpredictable and weak policy framework, Inadequate and deteriorating infrastructures support, for example, electricity, water, road, etc.

\section{Leadership and performance}

Performance is described as the attainment of the goals formulated by elected politicians in public organizations and by stakeholders in private organizations. Given that especially public organizations tend to have multiple goals, we will develop a typology of performance dimensions with explicit discussion of the distinctions between different dimensions. Existing research has consistently found that transformational leadership is positively associated with employee performance both generally (Bass \& Riggio 2006; Avolio et al., 2009) and in the public sector (Dvir et al., 2002; Trottier et al., 2008; Wofford et al., 2001).

Transformational leadership is expected to clarify organizational goals and increase the congruence between organizational and employee values and thereby positively affect motivation (Paarlberg \& Lavigna 2010; Ritz 2009; Bass \& Riggio 2006). This is expected to lead to lower absenteeism and higher performance (Lee et al., 2011; Kuoppala et al. 2008). Transactional leadership is expected to have a positive price/disciplining effect on performance, while the direction of the motivation crowding effect depends on the perception of the relevant reward/command systems as either commanding or supportive (Frey \& Jegen 2001; Weibel et al., 2010, Andersen \& Pallesen 2008; Jacobsen \& Andersen 2011, Georgellis et al., 2011).

Ethical leadership is important for every organization to succeed especially the public and private enterprises that work in an environment that has witnessed increased competition and regulation in the recent past. Ethical leadership was achieved through personal values, social values, moral values and values of competition are adhered to by all staff. The management trust is important for the enterprise as all the stakeholders in the industry look up to the management to undertake their business decisions with utmost trust to guide all the staff towards the attainment of the organizational goals, steer the rest of the staff towards the achievement of collective goals and resolving all conflicts without being bias or applying favouritism.

\section{Theoretical framework}

\section{Leader-Member Exchange (LMX) Theory}

This study is anchored on Leader-Member Exchange (LMX) developed by Dansereau, Graenand Haga (1975). The theory is a managerial behaviour theory. It explains the relationship between a leader and his/her subordinates. LeaderMember Exchange (LMX) theory explains the exchanges that occur between members of a "dyadic" relationship, which leads to the influence a leader makes on his followers. These exchanges have been classified as either those of close relationship that makes the leader have high leader-member exchange or as those of formal relationship with subordinates, that make the leader have a low leader-member exchange (Mowbray \& Ingley, 2011). The theory explains that leader-member exchange between a manager and the subordinates are relatively long-lasting, which influences the performance of the employees under the leader (Mowbray \& Ingley, 2011). Conversely, low leader-

OLANNYE, A. A. (2021). Application of ethical leadership and workers' performance: A perspectives from public and private owned enterprises. International Research Journal of Management, IT and Social Sciences, 8(3), 204-218 https://doi.org/10.21744/irjmis.v8n3.1468 
member exchanges have a negative relationship with the elements above (Mowbray \& Ingley, 2011). LMX theory has been hailed as one of the hallmarks of organisational efficiency and effectiveness (Northouse, 2010). Also, organisations that put LMX theory into practice largely attain their goals (Harris et al., 2009). The implication of LMX theory to this study is that the behaviour displayed by managers in the workplace, both in public and private sector organisations, in relating with subordinates and performing managerial roles is germane in encouraging openness and honesty to reduce unethical behaviours and ensuring effectiveness and efficiency in the running of the enterprises, either public or private organisations.

\section{Empirical Review}

Khuong \& Nhu (2015) investigated the effects of ethical leadership and organizational culture on employees' sociability as well as organizational commitment in the tourism sector. A quantitative approach was the major method used with a questionnaire distributed to 300 official employees in tourist companies such as travel agencies, tour operations, tourist destinations, hotels, and restaurants. The results indicated that employee sociability, involvement and mission culture had positive relationships with employees' organizational commitment. Additionally, the research suggested that to improve organization commitment, companies should: a) hire employees with sociable traits, b) apply involvement and mission culture for internal operation. Besides that, employee sociability positively affected ethical leadership and adaptive culture. Therefore, ethical leadership and adaptive culture indirectly affected organisational commitment through the sociability of employees. Also, Peter (2015) investigated the effects of ethical leadership on employee performance in the public sector in Uganda. A target population of 160 employees was surveyed. A structured questionnaire was self-administered to the employees to collect the data. Regression analysis and Pearson correlation coefficient were used to explain the nature of the relationship between ethical leadership and employee performance and the effects thereof. Results of the study reveal that employee performance is greatly influenced by ethical leadership. These have both policy and managerial implication which is discussed here.

\section{Materials and Methods}

The study is survey research which was chosen because it assists the researcher in getting the required data and also in answering the research questions. The population comprised of staff and management of selected parastatals and private firms in Asaba, Delta State. These firms were chosen based on nearness to the research base, a large number of employees as well as convenience. The sampling technique of simple random sampling was adopted. The population categorized and the sample elements centred on employees of these firms as seen below.

Table 2

Population of staff and Management of the selected public sector enterprises

\begin{tabular}{llllll}
\hline S/NO & Names of Organisation & \multicolumn{4}{c}{ Staff category } \\
\cline { 3 - 6 } & & Top Mgt & Middle & Lower \\
Mgt & Total \\
& & 5 & 15 & 95 & 115 \\
\hline 1 & Ministry of Information and Communication & 5 & 16 & 96 & 118 \\
2 & Ministry of Finance & 6 & 31 & 191 & 233 \\
Total & & 11 & & \\
\hline
\end{tabular}

Table 3

Population of staff and Management of the selected private sector enterprises

\begin{tabular}{llllll}
\hline S/NO & Names of Organisation & \multicolumn{4}{c}{ Staff category } \\
\cline { 3 - 6 } & & Top Mgt & Middle Mgt & Lower Mgt & Total \\
\cline { 3 - 5 } 1 & First Bank Plc & 11 & 21 & 120 & 152 \\
2 & Glo & 11 & 24 & 80 & 115 \\
& Total & 22 & 45 & 200 & 267 \\
& Grand Total & & & & 500 \\
\hline
\end{tabular}

Source: Researchers Field Survey, 2021 
A sample size of 221 was determined using the Taro Yamani formula out of a population of 733. The respondent's answers were used for the comparison of ethical leadership between public and private enterprise. The instrument used for the collection of data was a validated structured questionnaire and divided into six sections, namely A, B, C, D, E. Section (A) contained questions relating to the respondents' profile, section (B) contained information on Personal values on the leadership of private and public enterprises, Section (C) contained moral values on the leadership of private and public enterprises. Section (D) contained social values on the leadership of private and public enterprises while Section (E) contained values of competition on the leadership of private and public enterprises.

Baridam (2001), stated that deciding how the variables would be classified is the first step in organizing the observations of a study and the type of scale involved is determined by the nature of the phenomena under investigation. The operational measures of the variable are as follows: Predictor variable: Ethical leadership was measured by personal values and social values of competition. Criterion variable: The criterion variable (dependent variable) is public and private sector enterprise performance. The questions were measured using a Likert scale ranging from 1-5 (i.e. strongly agree, agree, undecided, disagree and strongly disagree). The statistical techniques adopted for processing the data and testing the hypotheses for this study were the mean using independent sample t-test via the use of statistical package for social science (SPSS) software version 21. Descriptive statistics and frequency analysis were used to explain the tables of the various variables. The mean response was tested using a student t-test.

Decision Rule: Reject null hypothesis (Ho) if the p-value is less than 0.05 (5\%) and if not, accept the null hypothesis and reject the alternate.

\section{Results and Discussions}

\section{Analysis of Data on Private Sector Enterprises}

The analysis for the study on private sector enterprises was carried out thus:

Table 4

Analysis of Personal Values in Private Sector Enterprises

\begin{tabular}{lllllll}
\hline S/N & Statement & \multicolumn{4}{c}{ Scale } \\
& & SA & A & U & D & SD \\
& & 5 & 4 & 3 & 2 & 1 \\
\hline 1 & My boss is interested in how I feel and & 188 & 8 & 3 & - & 1 \\
& how I am doing & $(94 \%)$ & $(4 \%)$ & $(1 \%)$ & - & $(1 \%)$ \\
2 & My boss is genuinely concerned about & 158 & 26 & 3 & 2 & 11 \\
& my personal development and success & $(79 \%)$ & $(13 \%)$ & $(1 \%)$ & $(1 \%)$ & $(6 \%)$ \\
3 & My boss pays attention to my success & 179 & 6 & 7 & 2 & 6 \\
& at work & $(89 \%)$ & $(3 \%)$ & $(4 \%)$ & $(1 \%)$ & $(3 \%)$ \\
& My boss cares about the happiness of & 189 & 4 & 6 & - & 1 \\
& his/her subordinates & $(94 \%)$ & $(2 \%)$ & $(3 \%)$ & - & $(1 \%)$ \\
\hline
\end{tabular}

Source: Researchers Analysis of Field Survey, 2021

The descriptive statistics showing the pattern of sample response, in comparison to personal values on private sector enterprises questionnaire items as indicated in table 3 above. 188(94\%) of the respondents strongly agreed that "My boss is interested in how I feel and how I am doing", 8(4\%) respondents, agreed, 3(1\%) were undecided, 1(1\%) of the respondents disagreed to the statement. A total of $158(79 \%)$ of the respondents strongly agreed that "My boss is genuinely concerned about my personal development and success", while $26(13 \%)$ agreed, $3(1 \%)$ of the respondents were undecided to the statement, $2(1 \%)$ disagreed while $11(6 \%)$ strongly disagreed. To the statement that "My boss pays attention to my success at work", 179(89\%) of the respondents strongly agreed, 6(3\%) agreed, 7(4\%) were undecided, while $6(3 \%)$ of the respondents disagreed. The statement "My boss cares about the happiness of his/her subordinates" had 189(94\%) respondents strongly agreed to the statement, 4(2\%) of the respondents agreed, 6(3\%) were undecided while $1(1 \%)$ strongly disagreed.

OLANNYE, A. A. (2021). Application of ethical leadership and workers' performance: A perspectives from public and private owned enterprises. International Research Journal of Management, IT and Social Sciences, 8(3), 204-218 https://doi.org/10.21744/irjmis.v8n3.1468 
Table 5

Analysis of Social Values on Private Sector Enterprise

\begin{tabular}{|c|c|c|c|c|c|c|}
\hline \multirow[t]{3}{*}{$\mathrm{S} / \mathrm{N}$} & \multirow[t]{3}{*}{ Statement } & \multicolumn{5}{|c|}{ Scale } \\
\hline & & SA & $\mathrm{A}$ & $\mathrm{U}$ & $\mathrm{D}$ & SD \\
\hline & & 5 & 4 & 3 & 2 & 1 \\
\hline 5 & $\begin{array}{l}\text { My head of department ensures we work } \\
\text { in an environmentally friendly manner }\end{array}$ & $\begin{array}{l}192 \\
(96 \%)\end{array}$ & $\begin{array}{l}5 \\
(2 \%)\end{array}$ & $\begin{array}{l}2 \\
(1 \%)\end{array}$ & - & $\begin{array}{l}1 \\
(1 \%)\end{array}$ \\
\hline 6 & $\begin{array}{l}\text { My head of department shows concern for } \\
\text { sustainability issues. }\end{array}$ & $\begin{array}{l}167 \\
(83 \%)\end{array}$ & $\begin{array}{l}25 \\
(12 \%)\end{array}$ & - & $\begin{array}{l}1 \\
(1 \%)\end{array}$ & $\begin{array}{l}7 \\
(4 \%)\end{array}$ \\
\hline 7 & $\begin{array}{l}\text { My head of department stimulates } \\
\text { recycling of items and materials in our } \\
\text { department }\end{array}$ & $\begin{array}{l}181 \\
(90 \%)\end{array}$ & 6 & $\begin{array}{l}6 \\
(3 \%)\end{array}$ & $\begin{array}{l}2 \\
(1 \%)\end{array}$ & $\begin{array}{l}5 \\
(3 \%)\end{array}$ \\
\hline 8 & $\begin{array}{l}\text { My head of department indicates what the } \\
\text { performance expectations of each group } \\
\text { member are }\end{array}$ & $\begin{array}{l}187 \\
(93 \%)\end{array}$ & $\begin{array}{l}5 \\
(3 \%)\end{array}$ & $\begin{array}{l}6 \\
(3 \%)\end{array}$ & - & $\begin{array}{l}2 \\
(1 \%)\end{array}$ \\
\hline
\end{tabular}

Source: Researchers Model Analysis of Field Survey, 2021

The descriptive statistics showing the social values of private enterprise in table 4 above. A total of 192(96\%) of the respondents strongly agreed that "My head of department ensures we work in an environmentally friendly manner", $5(2 \%)$ agreed to the statement, $2(1 \%)$ were undecided, while $1(1 \%)$ of the respondents strongly disagreed to the statement. A total of $167(83 \%)$ of the respondents strongly agreed that my head of department shows concern for sustainability issues, $25(12 \%)$ agreed, while $7(4 \%)$ of the respondents were strongly disagreed. The statement, my head of department stimulates recycling of items and materials in our department 181(90\%) of the respondents strongly agreed, $6(3 \%)$ agreed, $6(3 \%)$ were undecided, while $5(3 \%)$ of the respondents disagreed to the statement. The statement, that my head of department indicates what the performance expectations of each group member are $187(93 \%)$ of the respondents strongly agreed, $6(3 \%)$ were undecided, while $2(1 \%)$ of the respondents strongly disagreed.

Table 6

Analysis of moral values of private sector enterprises

\begin{tabular}{lllllll}
\hline S/N & Statement & \multicolumn{5}{c}{ Scale } \\
\hline & & SA & A & U & D & SD \\
& & 5 & 4 & 3 & 2 & 1 \\
\hline 9 & My boss keeps his/her promises & 189 & 8 & 2 & - & 1 \\
& & $(94 \%)$ & $(4 \%)$ & $(1 \%)$ & - & $(1 \%)$ \\
10 & My boss can be trusted to do the things & 164 & 26 & - & 1 & 9 \\
& he/she says. & $(82 \%)$ & $(13 \%)$ & - & $(1 \%)$ & $(5 \%)$ \\
11 & My boss can be relied on to honour his/her & 172 & 9 & 8 & 4 & 7 \\
& commitments & $(86 \%)$ & $(4 \%)$ & $(4 \%)$ & $(2 \%)$ & $(4 \%)$ \\
12 & My boss believes in trust and commitment & 186 & 6 & 5 & 1 & 2 \\
& & $(93 \%)$ & $(3 \%)$ & $(2 \%)$ & $(1 \%)$ & $(1 \%)$ \\
\hline
\end{tabular}

Source: Analysis of Field Survey, 2020

The descriptive statistics showing the pattern of sample response, in comparison to moral values on private enterprises questionnaire items as indicated in table 5 above. 189(94\%) of the respondents strongly agreed that my boss keeps his/her promises, $2(1 \%)$ were undecided, while $1(1 \%)$ of the respondents strongly disagreed with the statement. A total of 164(82\%) of the respondents agreed that my boss can be trusted to do the things he/she says while $9(5 \%)$ of the respondents strongly disagreed. The statement my boss can be relied on to honour his/her commitments 172(86\%) of the respondents strongly agreed, $8(4 \%)$ were undecided, while $7(4 \%)$ of the respondents strongly disagreed. A total of $186(93 \%)$ of the respondents strongly agreed that my boss believes in trust and commitment, $5(2 \%)$ of the respondents $\mathrm{E}$ undecided while 2(1\%) strongly disagreed. 
Table 7

Analysis of values of competition in private sector enterprises

\begin{tabular}{lllllll}
\hline S/N & Statement & \multicolumn{5}{c}{ Scale } \\
\hline & & SA & A & U & D & SD \\
& & 5 & 4 & 3 & 2 & 1 \\
\hline 13 & My boss ensures there is enough fund for & 192 & 5 & 2 & - & 1 \\
& running of the business & $(96 \%)$ & $(2 \%)$ & $(1 \%)$ & - & $(1 \%)$ \\
14 & My boss believes an intelligent and well- & 167 & 25 & - & 1 & 7 \\
& trained team achieves success & $(83 \%)$ & $(6 \%)$ & - & $(1 \%)$ & $(4 \%)$ \\
15 & My boss ensures there is flexibility in the & 181 & 6 & 6 & 2 & 5 \\
& organizational rules and regulations & $(90 \%)$ & $(3 \%)$ & $(3 \%)$ & $(1 \%)$ & $(3 \%)$ \\
16 & My boss embraces positive thinking to & 187 & 3 & 6 & - & 2 \\
& actualize organizational goals & $(93 \%)$ & $(3 \%)$ & $(3 \%)$ & - & $(1 \%)$ \\
\hline
\end{tabular}

Source: Researchers Analysis of Field Survey, 2021

The descriptive statistics show values of competition on private sector enterprises questionnaire items as exhibited in table 5 above. A total of $192(96 \%)$ of the respondents strongly agreed that my boss ensures there is enough fund for running the business, $2(1 \%)$ were undecided, while $1(1 \%)$ of the respondents strongly disagreed with the statement. A total of $167(83 \%)$ of the respondents strongly agreed that my boss believes an intelligent and well-trained team achieves success, 7(4\%) strongly disagreed, while 1(1\%) of the respondents were undecided. The statement, my boss ensures there is flexibility in the organizational rules and regulations $181(90 \%)$ of the respondents strongly agreed, $6(3 \%)$ were undecided, while $5(3 \%)$ of the respondents strongly disagreed. The statement, that my boss embraces positive thinking to actualize organizational goals $187(93 \%)$ of the respondents strongly agreed, 6(3\%) were undecided, while $2(1 \%)$ of the respondents strongly disagreed.

\section{Analysis of Data on Public Sector Enterprises}

The analysis for the study on public sector enterprises was carried out thus:

Table 8

Analysis of personal values in public sector enterprises

\begin{tabular}{lllllll}
\hline S/N & Statement & \multicolumn{5}{c}{ Scale } \\
\hline & & SA & A & U & D & SD \\
& & 5 & 4 & 3 & 2 & 1 \\
\hline 1 & My boss is interested in how I feel and & 192 & 5 & 2 & - & 1 \\
& how am doing & $(96 \%)$ & $(2 \%)$ & $(1 \%)$ & - & $(1 \%)$ \\
2 & My boss is genuinely concerned about my & 167 & 25 & - & 1 & 7 \\
& personal development and success & $(83 \%)$ & $(6 \%)$ & - & $(1 \%)$ & $(4 \%)$ \\
3 & My boss pays attention to my success at & 181 & 6 & 6 & 2 & 5 \\
& work & $(90 \%)$ & $(3 \%)$ & $(3 \%)$ & $(1 \%)$ & $(3 \%)$ \\
4 & My boss cares about the happiness of & 187 & 3 & 6 & - & 2 \\
& his/her subordinates & $(93 \%)$ & $(3 \%)$ & $(3 \%)$ & - & $(1 \%)$ \\
\hline
\end{tabular}

Source: Researchers Analysis of Field Survey, 2021

The descriptive statistics showing the pattern of sample response, in comparison to personal values on public sector enterprises questionnaire items as indicated in table 6 above. 8(4\%) of the respondents strongly agreed that "my boss is interested in how I feel and how I am doing", 1(0.9\%) respondents agreed, 3(2\%) were undecided, 126(63\%) of the respondents disagreed to the statement while 62(31\%) strongly disagreed. A total of 148(74\%) of the respondents strongly disagreed that "My boss is genuinely concerned about my personal development and success", while 21(10\%) agreed, 3(2\%) of the respondents were undecided to the statement, 26(13\%) disagreed while 2(1\%) strongly agreed. To the statement that "My boss pays attention to my success at work", 2(1\%) of the respondents strongly agreed, $16(8 \%)$ agreed, $17(8 \%)$ were undecided, 159(80\%) of the respondents strongly disagreed while $6(3 \%)$ of the

OLANNYE, A. A. (2021). Application of ethical leadership and workers' performance: A perspectives from public and private owned enterprises. International Research Journal of Management, IT and Social Sciences, 
respondents disagreed. The statement "My boss cares about the happiness of his/her subordinates" had 169(84\%) respondents strongly disagreed with the statement, $4(2 \%)$ of the respondents agreed, $16(8 \%)$ were undecided, $1(1 \%)$ disagreed while $10(5 \%)$ strongly agreed. This is due to poor incentives to workers, corruption, extravagance, red tape and inefficiency.

Table 9

Analysis of Social Values in Public Sector Enterprise

\begin{tabular}{|c|c|c|c|c|c|c|}
\hline $\mathrm{S} / \mathrm{N}$ & Statement & & & Sca & & \\
\hline & & $\overline{\mathrm{SA}}$ & $\bar{A}$ & $\mathrm{U}$ & $\mathrm{D}$ & SD \\
\hline & & 5 & 4 & 3 & 2 & 1 \\
\hline 5 & $\begin{array}{l}\text { My head of department ensures we work } \\
\text { in an environmentally friendly manner }\end{array}$ & $\begin{array}{ll}11 \\
(5 \%)\end{array}$ & $\begin{array}{l}4 \\
(2 \%)\end{array}$ & $\begin{array}{l}- \\
-\end{array}$ & $\begin{array}{l}170 \\
(85 \%)\end{array}$ & $\begin{array}{l}15 \\
(8 \%)\end{array}$ \\
\hline 6 & $\begin{array}{l}\text { My head of department shows concern for } \\
\text { sustainability issues. }\end{array}$ & $\begin{array}{l}7 \\
(3 \%)\end{array}$ & $\begin{array}{l}17 \\
(8 \%)\end{array}$ & $\begin{array}{l}1 \\
(1 \%)\end{array}$ & $\begin{array}{l}150 \\
(75 \%)\end{array}$ & $\begin{array}{l}25 \\
(13 \%)\end{array}$ \\
\hline 7 & $\begin{array}{l}\text { My head of department stimulates } \\
\text { recycling of items and materials in our } \\
\text { department }\end{array}$ & $\begin{array}{l}5 \\
(2 \%)\end{array}$ & $\begin{array}{l}6 \\
(3 \%)\end{array}$ & $\begin{array}{l}2 \\
(1 \%)\end{array}$ & $\begin{array}{l}100 \\
(50 \%)\end{array}$ & $\begin{array}{l}87 \\
(44 \%)\end{array}$ \\
\hline 8 & $\begin{array}{l}\text { My head of department indicates what } \\
\text { the performance expectations of each } \\
\text { group member are }\end{array}$ & $\begin{array}{l}2 \\
(1 \%)\end{array}$ & $\begin{array}{l}6 \\
(3 \%)\end{array}$ & - & $\begin{array}{l}187 \\
(93 \%)\end{array}$ & $\begin{array}{l}5 \\
(3 \%)\end{array}$ \\
\hline
\end{tabular}

Source: Analysis of Field Survey, 2020

The descriptive statistics showing the social values of private enterprise in table 7 above. A total of $170(85 \%)$ of the respondents disagreed that "My head of department ensures we work in an environmentally friendly manner", 4(2\%) agreed to the statement, no respondent was undecided, 11(5\%) of the respondents strongly agreed to the statement while $15(6 \%)$ strongly disagreed. A total of $150(75 \%)$ of the respondents disagreed that "my head of department shows concern for sustainability issues", $17(8 \%)$ agreed, $7(2 \%)$ of the respondents were strongly agreed while $25 \quad(13 \%)$ strongly disagreed. The statement, my head of department stimulates recycling of items and materials in our department $100(50 \%)$ of the respondents disagreed, 17(8\%) agreed, 1(1\%) were undecided, 25(13\%) of the respondents disagreed to the statement while 7(3\%) of the respondents strongly agreed. The statement, that "my head of department indicates what the performance expectations of each group member are", 187(93\%) of the respondents disagreed, none were undecided, $5(3 \%)$ strongly disagreed, $2(1 \%)$ of the respondents strongly agreed while $6(3 \%)$ agreed.

\section{Data Analysis}

The result of the student t-test is shown in the table below:

Table 10

Independent samples test

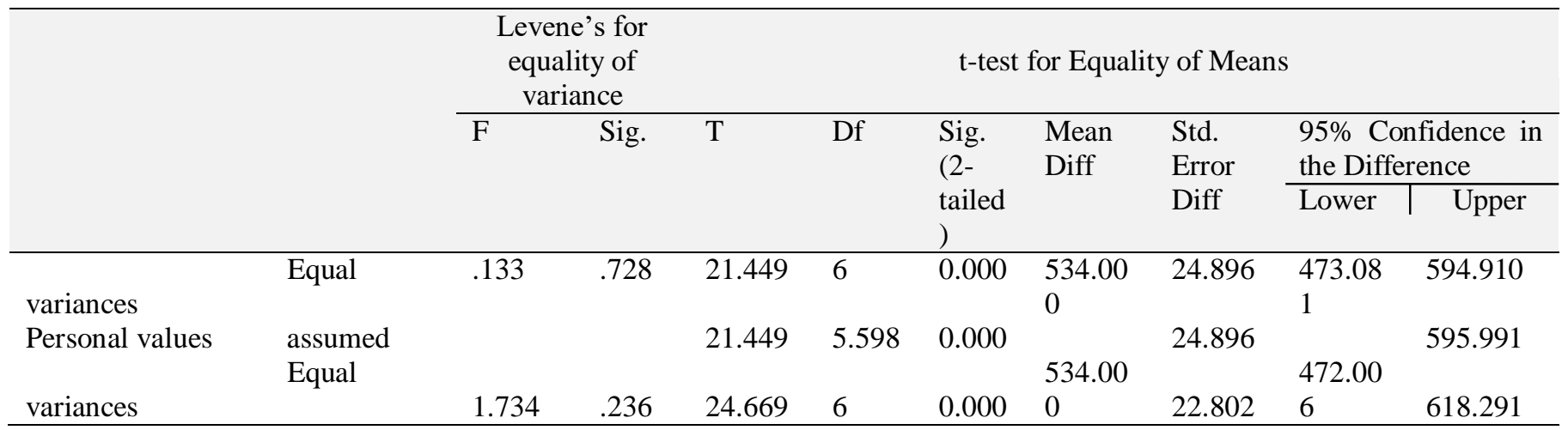




\begin{tabular}{|c|c|c|c|c|c|c|c|c|c|c|}
\hline variances & $\begin{array}{l}\text { not assume } \\
\text { Equal }\end{array}$ & & & 24.669 & 4.234 & 0.000 & $\begin{array}{l}562.50 \\
0\end{array}$ & 22.802 & $\begin{array}{l}506.70 \\
6\end{array}$ & 624.450 \\
\hline Social values & assumed & 15.704 & .007 & 28.430 & 6 & 0.000 & & 22.854 & & 705.672 \\
\hline variances & $\begin{array}{l}\text { Equal } \\
\text { Not }\end{array}$ & & & & & & $\begin{array}{l}562.50 \\
0\end{array}$ & & $\begin{array}{l}500.55 \\
0\end{array}$ & \\
\hline $\begin{array}{l}\text { assumed } \\
\text { variances }\end{array}$ & Equal & & . & & & & $\begin{array}{l}649.75 \\
0\end{array}$ & & $\begin{array}{l}593.82 \\
8\end{array}$ & \\
\hline
\end{tabular}

Source: Computed from field survey data using SPSS Ver. 21 software

The decision rule for the study stated that we should reject the null hypothesis (H0) if the p-value is less than $0.05(5 \%)$ and if not, do not reject the null hypothesis. Therefore, it was indicated in table 8 that personal values which is the first variable revealed that there is no significant difference in ethical leadership and employee performance between the Public and Private enterprise ( $\mathrm{Sig}=.728, \mathrm{P}>0.05)$. Similarly, Social values which is the second variable showed that there is no significant difference in ethical leadership and employee performance between the Public and Private enterprise ( $\mathrm{Sig}=.238, \mathrm{P}>0.05$ ). The two independent variables are the factors that determine ethical leadership and employee performance between the Public and Private enterprise.

\section{Hypotheses Testing}

Hypothesis One

$\mathrm{H}_{\mathrm{O} 1}$ : There is no significant difference in personal values on ethical leadership between the public and private enterprises.

Since the P-value calculated in table 8 is greater than the critical level of significance $(.728>0.05)$, the null hypothesis was accepted while the alternate hypothesis was rejected this implies that there is no significant difference in personal values on ethical leadership and employee performance between public and private enterprise.

\section{Hypothesis Two}

$\mathrm{H}_{\mathrm{O} 2}$ : There is no significant difference in social values on ethical leadership between the public and private enterprises.

Since the p-value calculated in table 8 is greater than the critical level of significance $(.238>0.05)$, there was a need to accept the null hypothesis and reject the alternate hypothesis. This showed that there is no significant difference in social values on ethical leadership and employee performance between public and private enterprise.

\section{Discussion of Findings}

Personal values on ethical leadership and employee performance on public and private enterprise

From the results of frequency analysis in both the public and private sector enterprises, it revealed that the majority of the respondents overwhelmingly responded either positively or negatively to the various statements with regards to personal values on ethical leadership and employee performance on both the public and private enterprise. Furthermore, it was reported in table 8 using the student t-test that personal values have no significant difference on ethical leadership and employee performance of the public and private enterprise ( $\mathrm{Sig}=.728, \mathrm{P}>0.05)$.

These findings are in line with Ebitu (2012) who affirmed that ethical leadership is applicable to accentuate an ethical consensus in a business relationship, activities and actions with customers to survive, stabilize and grow; as customers expect a level of acceptable conduct from business organizations through product/service quality, avoiding deceptive adverts, product safety and fairness in all dealings. Also in tandem with Haque (2001) public sector has been under increasing pressure to adopt private sector orientations. Lynge (2013), this, in inference, shows that there are inherent peculiarities involved in the leadership practices of both sectors in developing countries.

OLANNYE, A. A. (2021). Application of ethical leadership and workers' performance: A perspectives from public and private owned enterprises. International Research Journal of Management, IT and Social Sciences, 8(3), 204-218 https://doi.org/10.21744/irjmis.v8n3.1468 
Social values on ethical leadership and employee performance on public and private enterprise

From the results of frequency analysis in both the public and private sector enterprises, it revealed that the majority of the respondents overwhelmingly responded either positively or negatively to the various statements about social values on ethical leadership and employee performance on public and private enterprise. Furthermore, table 8 showed that social value has a positive influence on private enterprise performance ( $\mathrm{Sig}=.238, \mathrm{P}>0.05$ ). Furthermore, it was reported in table 8 using the student t-test that there is no significant difference between social values on ethical leadership and employee performance of the public and private enterprise $(.238>0.05)$.

These findings are consistent with the view of Matanmi (2007) that the concept of efficiency as applicable to the context of the employment relationship is a function of proper management of employees at work, including the adherence to workplace ethical standards. This is also in agreement with Qiu (2013) who posited that absenteeism, unwarranted breaks, stealing of organization property, converting office equipment for personal use, gossiping are characteristic of unethical conducts and are liable to affect public and private enterprises. Hence, the commitment and satisfaction become immaterial if it does not infuse with integrity Arnold (2009).

\section{Conclusion}

In as much as the public sector is controlled by the government and the private sector is controlled by individuals, which makes them different but the truth remains that ethical rules and regulations are guiding the running of both sectors. Therefore, from the study, though there may be bureaucratic bottlenecks in the public sector that makes decisions a little bit challenging due to the hierarchical nature of the public sector; it remains that ethics and corporate governance rules are enshrined and remains the same with the private sector enterprises. Ethical leadership is very crucial for any organization (both public and private) to succeed. Leaders' ethical behaviours such as clarifying roles, sharing power, and acting fairly signals that these leaders can be seen as ideal representatives of the group and that in turn implies they can be trusted. Furthermore, such trusted leaders are perceived as more effective. If leaders are ethical, they can ensure that ethical practices are carried out throughout the organization. The enterprise must maintain the learning environment for its employees. So, there must be collaborative efforts of the leaders and the organizational employees to tow the ethical highway to enhance their performance. These ethical values are important factors for organizational success in both public and private enterprises.

\section{Recommendations}

1) The efforts in promoting ethical leadership practices in the public and private enterprise must start and be perceptible on the personal values of the staff from top to bottom.

2) To individually evaluate areas for ethical risks such as guidance issues, monitoring and adherence to ethical codes, monitoring policy and overseeing ethics training programmes, the CEO must be the chief ethic officer.

3) The ethical values, interpersonal qualities and capabilities to carry out the different tasks as needed by the organizations.

\section{Conflict of interest statement}

The author declared that have no competing interests.

Statement of authorship

The author has a responsibility for the conception and design of the study. The author has approved the final article.

\section{Acknowledgments}

I am grateful to two anonymous reviewers for their valuable comments on the earlier version of this paper. 


\section{References}

Aksiana, I. B. W., \& Sujana, I. K. (2019). Effect of Risk Preference, Professional Domination, Information, and Professional Relationship on Ethical Decision Making of Tax Consultants. International Research Journal of Management, IT and Social Sciences, 6(4), 174-179.

Arnold, D. N. (2009). Integrity under attack: The State of Scholarly Publishing. News Journal of the Society for Industrial and Applied Mathematics, 42(10), 1 -3.

Avey, J. B., Wemsing, T. S. \& Palanski, M. E. (2012). Exploring the process of ethical leadership: The mediating role of employee voice and psychological ownership. Journal of Business Ethics, 107, 2 1-34.

Avolio, B.J.; R.J. Reichard, S.T. Hannah, F.O. Walumbwa \& A. Chan (2009): A meta-analytic review of leadership impact research: Experimental and quasi-experimental studies. The Leadership Quarterly 20(5): 764-784.

Bass, B.M. \& Riggio, R.E. (2006): Transformational leadership, 2nd ed. Mahwah, NJ: Lawrence Erlbaum Associates.

Bass, B.M., Avolio, B.J., Jung, D.I. \& Berson, Y. (2003): Predicting unit performance by assessing transformational and transactional leadership. Journal of Applied Psychology, 88(2):207-21 8.

Bennis, W., \& Nanus, B. (2007). Leadership: The strategies for taking charge: New York: Harper \& Row.

Berghofer, D. \& Schwartz, G. (ud). Ethical Leadership: Right Relationship and1h Emotional Bottom Line, The Gold Standard for Success, The Institute for Ethical Leadership. Retrieved Online on July 16, 2011, at HTTP// www.ethical leadership. corn

Berrone, P., Surroca, J. \& Tribó J. A. (2007) Corporate Ethical Identity as a Determinant of Firm Performance: A Test of the Mediating Role of Stakeholder Satisfaction, Journal of Business Ethics, 76(1): 35-53.

Brown, M. E., \& Trevino, L. K. (2006). Ethical leadership: A review and future directions. The Leadership Quarterly, 17(6), 595-6 16.

Brown, M. E., \& Treviño, L. K. (2006). Ethical leadership: A review and future directions. The leadership quarterly, 17(6), 595-616. https://doi.org/10.1016/j.leaqua.2006.10.004

Brown, M. E., Treviflo, L. K., \& Harrison, D. A. (2005). Ethical leadership: A social learning perspective for construct development and testing. Organizational Behavior and Human Decision Processes, 97(2): 117-134.

Brown, M. E., Treviño, L. K., \& Harrison, D. A. (2005). Ethical leadership: A social learning perspective for construct development and testing. Organizational behavior and human decision processes, 97(2), 117-134. https://doi.org/10.1016/j.obhdp.2005.03.002

Ciulla, J. B. (2005). Integrating leadership with ethics: is good leadership contrary to human nature? In P. J. Doh \& S. A. Stumpf (Eds.), Handbook on responsible leadership and governance in global business (159-179). Cheltenham UK: Edward Elgar Publishing Limited.

Dansereau, F., Graen, G., \& Haga, W. J. (1975) A vertical dyad linkage approach to leadership within formal organisations: A longitudinal investigation of the role making process. Organisational Behaviour and Human Performance, 13(1), 46-78.

Demeter, C. M., \& Tapardel, A. C. (2013). Public and private leadership and performance management, Change and Leadership, 17, 162-167.

Dewi, I. G. A. A. P., \& Dewi, P. P. (2018). Big Five Personality, Ethical Sensitivity, and Performance of Auditors. International research journal of management, IT and social sciences, 5(2), 195-209.

Ebitu, E. T. (2012). Promoting ethical behaviour in business in Nigeria and the international market, International Journal of Innovation in Management Sciences, 4(2): 126 - 130.

Ekpo, A. H., \& Umoh, O.J. (2008). Overview of the Nigerian Economic Growth \& Development. Abuja, Nigeria: CBN Research Units.

Freeman, R. E. \& Stewart, L. (2006). Developing ethical leadership. Bridge Papers. Document Number)

Freeman, R. E., Martin, K., Parmar, B., Cording, M., \& Werhane, P. H. (2006). Leading through values and ethical principles. In R. J. Burke \& C. L. Cooper (Eds.), Inspiring Leaders, Routledge Publishing. Oxford, UK.

Gallagher, A., \& Tschudin, V. (2010). Educating for ethical leadership. Nurse education today, 30(3), $224-227$. https://doi.org/10.1016/j.nedt.2009.11.003

Kannair, J. (2007). The Ethical Mind. Harvard Business Review, 85(3): 51-56.

Kim, W. G., \& Brymer, R. A. (2011). The effects of ethical leadership on manager job satisfaction, commitment, behavioral outcomes, and firm performance. International Journal of Hospitality Management, 30(4), 1020-1026. https://doi.org/10.1016/j.ijhm.2011.03.008

Kuoppala, J. A., Larnminpaa, J., Liira, M.D. \& Vainio, H. (2008): Leadership, JOb Well-Being, and Health Effects A Systematic Review and a Meta-Analysis. Journal of Occupational \& Environmental Medicine 50(8):904-915.

Lawanson, O.I.. (2002). Promotion of Non-Oil Export in the Nigerian Economy. FBN Quarterly Review, 2(1), March.

OLANNYE, A. A. (2021). Application of ethical leadership and workers' performance: A perspectives from public and private owned enterprises. International Research Journal of Management, IT and Social Sciences, 8(3), 204-218 https://doi.org/10.21744/irjmis.v8n3.1468 
Lee, D., Coustasse, A. \& Sr. Sikula, A. (2011): Transformational leadership äii1 workplace injury and absenteeism: Analysis of a National Nursing Assistant Survey. Health Care Management Review: 36(4):380-387.

Mathews, M. P. (2002). Nigeria: Current Issues and Historical Background. New York: Nova Science Publishers, Inc.

Northouse, G. (2007). Leadership Theory and Practice, (3rd edn), Thousand Oak, London, New Delhi, Sage Publications, Inc.

Northouse, P. G. (2010). Public administration theory as discourse. Administrative Theory and Practise, 12, $132-139$.

Obadan, M.I (2000) Privatization of Public Enterprises in Nigeria: Issues and Conditions for Success in the Second Republic Ibadan: National Center for Economic Management and Administration.

Ogundele, O. J. K. (2012). Management and organisation: Theory and behaviour. Lagos: Molofin Nominees.

Olannye, A.P. (2006). Research Methods For Business: A Skill Building Approach, Lagos: Pee] en Publishers.

Osemeke, M. (2007). Banking Reforms in Nigeria and its Impact on Poverty Alleviation, Journal of Business \& Management Studies (JBMS), Ozoro, Nigeria: Delta State Polytechnic..2(1),.72-81.

Paarlberg, L.E. \& Lavigna, B. (2010): Transformational Leadership and Public Service Motivation: Driving Individual and Organizational Performance. Public Administration Review, 70:710-718.

Perreault, G. (2010). Ethical Followers: A Link to Ethical Leadership. Journal of Leadership \& Organizational Studies, 4(1): 7 8-89.

Peter, A. O. (2015). Effect of Ethical Leadership on Employee Performance in Uganda. Net Journal of Business Management, 3(1). 1-12

Pollitt, C. \& Geert, B. (2004) Public Management Reform: A Comparative Analysis. 2nd Edition. New York: Oxford University Press.

Qiu, T. \& Peschek, B. S. (2013) The effect of interpersonal counter-productive workplace behaviours on the performance of New Product development Teams. American Journal of Management Vol. 12(1).

Resick, C.J., Hanges, P.J., Dickson, M.W. \& Mitchelson, J.K. (2006) A Cross-Cultural Examination of the Endorsement of Ethical Leadership, Journal of Business Ethics, 63(4): 345-359.

Ritz, A. (2009): Public service motivation and organizational performance in the Swiss federal government. International Review of Administrative Sciences, 75(1): 53-78.

Robbins, S. P. \& Judge, T. A. (2013).Organisational behaviour, 15th edition. England: Pearson Education Limited

Toor, S. \& Ofori, G. (2009) Ethical Leadership: Examining the Relationships with Full Range Leadership Model, Employee Outcomes, and Organizational Culture, Journal of Business Ethics, 90: 533-547.

Trevino, L. K., \& Brown, M. E. (2005). Managing to be ethical: Debunking five business ethics myths. Strategic human resource management: theory and practice.

Uche, C. B. N. (2012). Unethical behaviour of managers in the public and private corporate organisations in Nigeria. (the University of Lagos, An Unpublished PhD Thesis).

Walumbwa, F. O., Mayer, D. M., Wang, P., Wang, H., Workman, K., \& Christensen, A. L. (2011). Linking ethical leadership to employee performance: The roles of leader-member exchange, self-efficacy, and organizational identification. Organizational behavior and human decision processes, 115(2), $204-213$. https://doi.org/10.1016/j.obhdp.2010.11.002

Wayne, L. (2009). A promise to be ethical in an era of immorality. New York Times. Retrieved on November 4, 2009, from http://www.nytimes.com/ 2009/05/30/business

Yukl, G. (2006). Leadership in organizations, 6th edition. New Jersey: Pearson Prentice Hall Upper Saddle River, NJ. 